\title{
3. 只木層について
}

長 谷川 善 和

序

只木採石場の洞窟堆皘物は粒度その他の性質によつて大体五層に分けられ、これらを総称 して只木層 ${ }^{1)}$ と呼ぶことにする。

只木層は分岐洞窟の形態に支配された堆積物で、堆積物の大部分は磞砂の混じた黄褐色緻 密粘土層よりなる。部分的にその他の地層がその上飞堆皘し、化石は黄褐色絰密粘土層の上 部の含啋粘土層に多く含まれ、それらは流入又は落込みの可能性が大きい。

洞が壁面向つて右側と左側飞二分され、堆皘物の堆積状態も、洞の形態に影響されて、大 体左右二分されている。以下主要部の層序、敊よび洞との関係を中心記す。Fig. 1 は、発 掘時壁面に現われた断面の状態を示したものである。但し、 $\mathrm{a}-\mathrm{a}^{\prime}$ 線より右（第一区域とす る）と $\mathrm{b}-\mathrm{b}^{\prime}$ 線より左（第三区域とする）の壁面は、注ぼ平行で $\mathrm{EW}$ 方向南佰面し、中間 部（第二区域とする）は大体 SN 方向西佰面し、三者の関係は乙状てある。この図に扬いて はそれらを平面上に示してある。発掘主要部は第一区域である(現採石面)。 $\mathrm{a}-\mathrm{a}^{\prime}$ 線までは。 測量基準線によつて測量を行つたが、第二・第三区域は第一区域に準じて、折尺及び巻尺に より測定したものである。堆積状況を知る上に重要であるので同じく図示する。

洞窟の形態

断面に見る限りでは、石灰岩体の最高部辺に洞口をもつ縦穴が、下方で左右に二分し、横 穴となつて発達する。初期の洞形成の際には洞窟石灰岩（トラバーチンと呼ぶ）発達が注と んどみられない、岩窟状分岐洞窟（Cave, Höhle）をなす。すおち第一区域左 端部（K・ $\mathrm{L} \cdot \mathrm{M}$ 域）は縦穴で、左側 O-F'は典型的横穴となる。右側では K-D 間横穴となつている が、その上下には綐穴が連絡し、第一区域が最も複雑な形態をなす。大部分が堆皘物によつ て満されているが、イ〜トの部分で空洞となつて開口し、洞穴石灰岩の発達が小規模にみら れる。への奥は明らかに外部に通じている。グリッドの $\mathrm{E} \cdot \mathrm{O}, \mathrm{A} \cdot \mathrm{O}$, の上部も地上飞通じて いたと思われるが明らかでない。

洞窟形成の時期

主洞は隣接している、怙宮の裏乎の段丘形成と密接な関係があると思うが、具体的な証拠 なく、地形学的考察によつて、結論するには早計である。現在のところ産出する動物種の比 較に上る間接的方法以外ない上万である。凡そ洪皘世後期であろらかと思われる。

層序

I. 黄褐色緻密粘土層

最下部層である。一部赤褐色をなしている。黄褐色緻密粘土が主であるが、砂・チャート 角碎が interfinger（指交）状に混つたり、時にはレンズ状に混り、必ずしも均質でなく、

1）鹿間・長谷川（1955）が竜ケ石累層に含まれることを指摘しているが、便宜上只木層と命名する。 


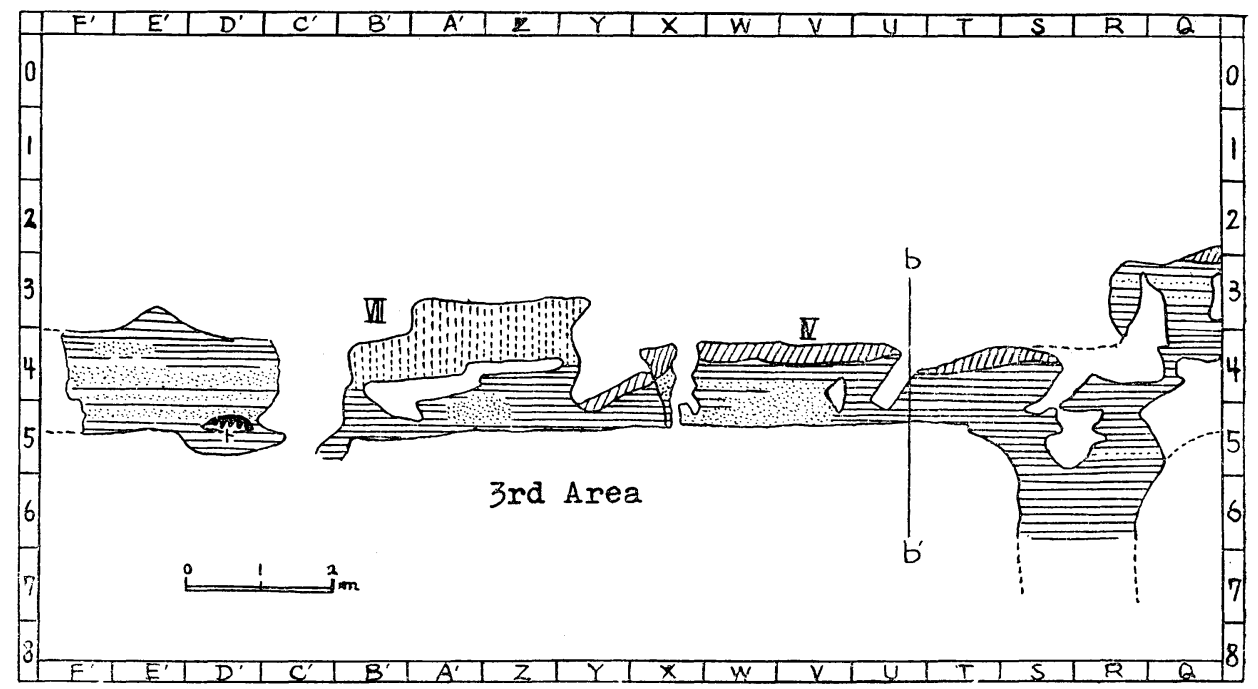

Fig. 1 Section showing stratigraphy of the Tadaki formation (fissure deposits). Dotted lines indicate the connection of fissures.

複雑な層相変化が観察される。下部に粘土が主で上部に砂質となり、J-M・O-3 域で、一部 がトラバーチンのため角礫質となる。最上部は次に述べる含角礫粘土層に漸移するが、本来 これまでを一つにすべきものである。これらは、現在の経験では、洞形成と前後して生じる 残留粘土層ともいうべきものである。第二区域から Felis, Cervus の化石を産出している。

II. 含碩粘土層

下部層に整合に重なる。本来が下部層に属すべきものである。2〜 $5 \mathrm{~cm}$ 大のチャート、頁 岩なぞ古生層起源の淘汰の悪い礫が多い。下部層の中にレンズ状に含まれるるのと何ら異な らない。最も厚いところで $1 \mathrm{~m}, \mathrm{H} \rightarrow \mathrm{A}, 3-5$ の方向を示しながら堆積する。八洞の両壁に トラバーチンで被覆された礫と同一物であるので、八洞の方向から下に向つて堆積したもの である可能性が大さい。Sinomegaceroides, Cervus, Palaeoloxodon, Homo 等の化石種 は注とんど本層より産出する。この層の主要部分は、典型的な洞内流入堆積物である。下部 の残留粘土が上方に向つて次第に減じて流入性の堆積に変つている状態が示されている。従 つて化石種も、この限りでは流入又は落込みによるものであることを示唆している。

III. 洞窟石灭岩（トラバーチン）

ほとんどが第一区域にみられるが、発達が恶い。イ〜ト何れも新しい洞の形成によつて出 来たというほどのものでなく、さしろ古い洞内の堆積物が一部流出した、小さい空隙を埋め たようなものである。例总ばイ洞の場合は最下部層の一部を侵蝕して出来た空洞である。こ の場合には、周囲の粘土その他が角礫質になつて和り、鐘乳石の形成と同時に堆積物にも浸 み込んで固結したことがわかる。この作用は著しいものではないが、相当広範囲に亘つたと 思われる節もある。口洞の場合は堆積物の上にトラバーチンが被覆したのちに、下部の粘土 層が削剝を受けている。八洞では、両壁の中程にトラバーチンにとじ込められた、礫層が見 


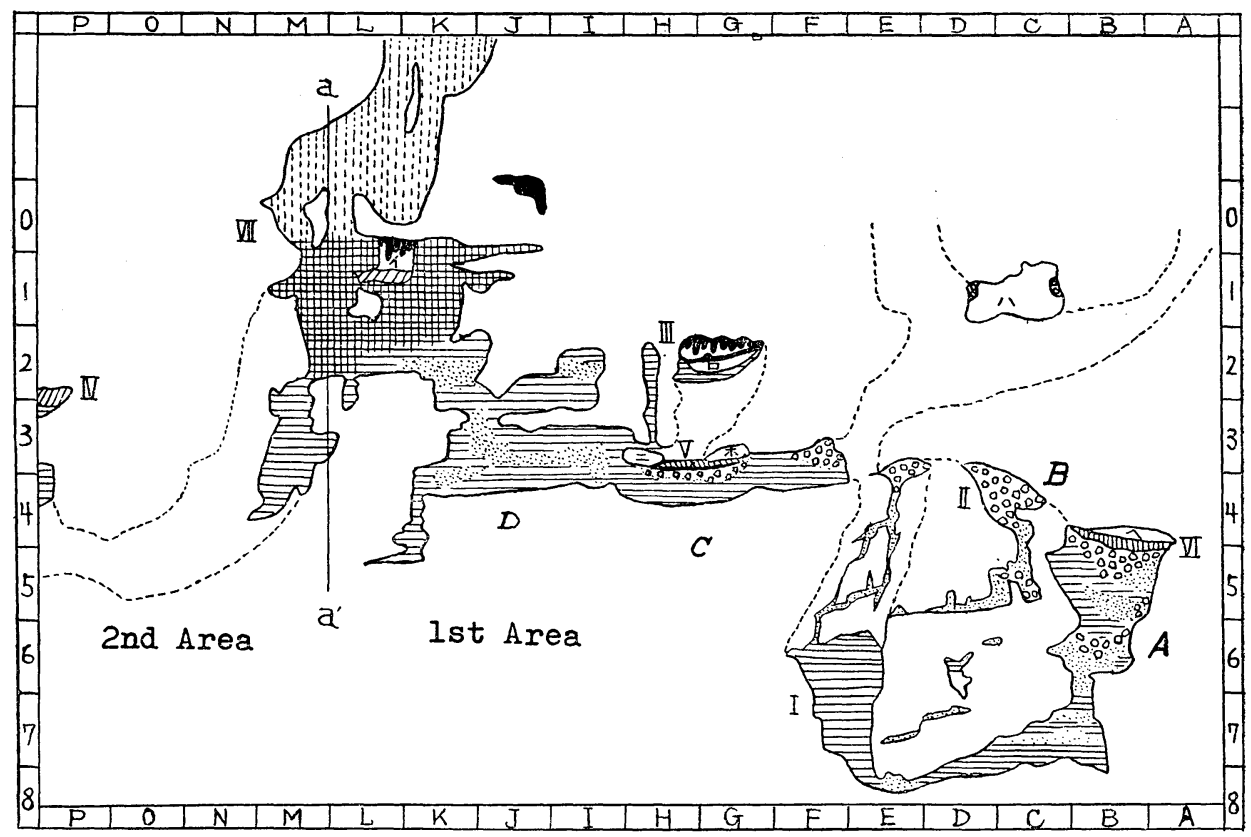

I. Yellowish brown compact clay, II. Gravel-bearing clay, III. Travertine, IV. Porous black sand, V. Yellowish brown sandy clay, VI. Yellowish brown clayey sand, VII. Talus.

られるが、これは明らかに以前この高さまで碚層の堆積があつて、侵蝕されたあとをトラバ 一チンが被覆したものであろう。しかしながらいずれの場合に私いても、その規模は小さい。

IV. 多孔質黒色砂層

$\mathrm{L} \cdot 1$ (イ洞) から $\mathrm{R} \cdot \mathrm{Q}, 2 \cdot 3$ を通つて、 $\mathrm{T}-\mathrm{Z}$ 間に分布する。最高 $50 \mathrm{~cm}$ から平均 $30 \mathrm{~cm}$

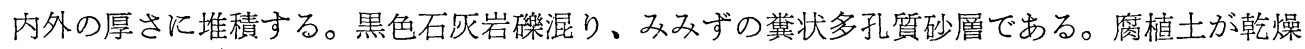
した状態のものである。L・1に执いて明らかな如くイ洞形成後堆積したものである。第一区 域に同様なものはみられない。岩水寺黒土層、白岩黒色粘土層に対比される。

V. 黄褐色砂質粘士層

含碩粘士層とは薄いトラバーチンによつて境されている。 $\mathrm{H} \cdot \mathrm{G} \cdot 3$ から F·3 の奥に僅かに 出ているが、黄褐色緻密粘土層と本質的に変りなく、その分布範囲の狭いこと、ロ洞に和け る粘土層の削剝状態などより推して、下部層の再堆積したものと考えられる。黒色砂層との 上下関係はわからない。

VI. 黄褐色粘土質砂層

ホ洞 $(\mathrm{A} \cdot \mathrm{B} \cdot 4)$ 入口から奥に向つて広く分布する。洞内二ケ所が石欧岩体右側の數の中に 開口した、二本の縦支洞によつて外部に連絡して和り、本層は明らかに外部より流入したも のであり、現在も落込みがみられる。 $50 \mathrm{~cm}$ 内外の厚さをもつ。下位層表面は不規則である が、それを埋め立てて表面は平坦化している。下位層の表面はすでに多少とも風化作用が働 いているため、砅質粘土層、粘土層でない砂質部との境界は明瞭でない。本層よりは Nycterentes と蛇の保存良好な骨片を得ている。いずれるごく近年埋没したものと考えられる。 
VII. 崩 落 土

第一区域 J-M の上部、第三区域 $\mathrm{Y}-\mathrm{B}^{\prime}$ の上部に崩落土が多い、これらはチャート、石网 岩などの础を含む黄褐色砂又は粘土質砂で、採石による石乍岩体の崩壊によつて、表面にあ つたものがずり落ちたものである。雨水がかつると粘質を増し、下部層の一部々誤解するこ とがあるが、石灭岩破片を含むのでこれらと区別出来る。洞内堆積物では、こうした種類の ものと、古い地層との区別がしばしば困難なことがあるので、当地域での区別点を特に記し ておく。先にのべた黄褐色粘土質砂層にも同様淘汰のわるい石灭岩礫を含むことから、同様 に区別出来る。

(横浜国立大学学芸学部地学教室) 